Article

\title{
Regulated Deficit Irrigation as a Water-Saving Strategy for Onion Cultivation in Mediterranean Conditions
}

\author{
Abdelsattar Abdelkhalik 1,2, Bernardo Pascual 1,3, Inmaculada Nájera ${ }^{4}$, Carlos Baixauli 4 \\ and Nuria Pascual-Seva $1,3, *$ (D) \\ 1 Departamento Producción Vegetal, Universitat Politècnica de València, Camí de Vera s/n, \\ 46022 Valencia, Spain \\ 2 Horticulture Department, Faculty of Agriculture, Fayoum University, Fayoum 63514, Egypt \\ 3 Centro Valenciano de Estudios sobre el Riego, Universitat Politècnica de València, Camí de Vera s/n, \\ 46022 Valencia, Spain \\ 4 Centro de Experiencias de Cajamar Paiporta, Camino del Cementerio Nuevo s/n, 46200 Valencia, Spain \\ * Correspondence: bpscual@prv.upv.es
}

Received: 8 July 2019; Accepted: 5 September 2019; Published: 7 September 2019

\begin{abstract}
Field experiments were performed for two growing seasons in Spain under Mediterranean conditions to evaluate the response of onion growth, plant water status, bulb yield, irrigation water use efficiency (IWUE), and gross revenue to regulated deficit irrigation strategies (RDI). Seven irrigation treatments were utilized, including the application of $100 \%$ irrigation water requirements (IWR) during the entire growing season and the application of $75 \%$ or $50 \%$ of the IWR during one of the following growth stages: the vegetative growth, bulbing, and bulb ripening stages. The deficit irrigation strategies tested decreased marketable yields to greater or lesser extents; therefore, if water is readily available, full irrigation would be recommended. The RDI with $50 \%$ of the IWR during the bulb ripening stage led to important water savings (22\%) and to slight decreases in yield (9\%), improving IWUE (20\%) compared with full irrigation, and this strategy can be recommended under a severe water shortage. A satisfactory bulb yield was obtained with RDI with $75 \%$ of the IWR during the bulb ripening stages, resulting in a lower reduction in yield (4\%) and in an increased IWUE (9\%); this strategy is an advisable strategy for onion production under a mild water shortage in Mediterranean conditions.
\end{abstract}

Keywords: irrigation water requirements; irrigation water applied; irrigation water use efficiency; volumetric soil water content; relative water content; membrane stability index; plant growth; bulb yield; yield response factor; gross revenue

\section{Introduction}

Onion (Allium cepa L.) is the second most important vegetable crop worldwide, producing approximately 98 million tons on 5.20 million ha in 2017. Globally, China, India, and the USA were the major onion-producing countries in 2017, whereas Russia, the Netherlands, and Spain are the principle onion producers in the European Union [1]. Onions are traditionally cultivated in Valencia (Spain) in winter within the traditional crop rotations.

Irrigation water is a crucial resource for sustainable agricultural development worldwide. In arid and semiarid areas, including the Mediterranean region, water scarcity is becoming critical, increasing competition for water among agricultural, industrial, and urban consumers [2,3]. Agriculture is the largest user of water worldwide, accounting for approximately $69 \%$ of the total consumption of freshwater [4]. The total irrigated agricultural area was approximately 40 million ha in 1900, and it 
has increased more than eightfold worldwide over the last century to approximately 325 million ha; consequently, water withdrawal has increased from less than $600 \mathrm{~km}^{3}$ year ${ }^{-1}$ to approximately $4000 \mathrm{~km}^{3}$ year $^{-1}[4,5]$. Population growth, urbanization, the increase of irrigated agriculture, and the greater incidence of drought caused by climate change, particularly in the Mediterranean area, indicate that irrigation water demand, as well as irrigation costs, will continue to increase in the future [6]. Furthermore, the Mediterranean area has low water resources per habitant, and is thus considered a water-stressed area and faces a great challenge to cope with water scarcity $[7,8]$.

The increases in irrigation costs and water scarcity have increased interest in improving water productivity for irrigated agriculture $[9,10]$, which can be achieved by both efficient irrigation design and appropriate irrigation management $[11,12]$. Within this context, a deficit irrigation strategy is a sustainable practice of applying irrigation levels that are below the optimum crop water requirements, improving water productivity $[10,13-17]$. Plants respond differently to water reductions applied at different development stages; therefore, their yield responses vary depending on their sensitivity at each growth stage [2,18]. Regulated deficit irrigation (RDI) is a stage-based DI and consists of imposing water deficits at particular phenological stages, when the crop is less sensitive to water stress $[10,17,19]$. Therefore, to apply the RDI approach effectively, identifying the most critical growth stages for a specific crop species and cultivar is needed [16].

Irrigation water use efficiency (IWUE) is a key variable used to assess the efficiency of irrigation water use in crop production [20] and is a practical index for the assessment of plant responses to deficit irrigation [16,19]. Enhancing IWUE in irrigated agriculture increases the yield per unit of water applied [21]. Under limited water conditions, one of the main goals of farmers and researchers is to maximize IWUE rather than to increase yields [19]. The yield response factor $\left(K_{y}\right)$ represents the relationship between a relative yield decrease and a relative water deficit, providing a quantitative evaluation of yield responses to soil water deficits during the growing season [22,23]. The relative water content (RWC) and membrane stability index (MSI) are indicators of plant water status [24]. The RWC refers to the plant water content, and has been used as a meaningful index for dehydration tolerance, while the MSI detects the integrity of cell membranes, and has also been widely used as an indicator of leaf desiccation tolerance [25].

Onion plants possess shallow-root systems, with most parts of the roots in the top $0.20 \mathrm{~m}$ of the soil [26,27]; therefore, onions require frequent and light water applications to avoid incurring large soil water deficits $[28,29]$. Hence, onions are very sensitive to water stress, requiring adequate irrigation management to achieve high commercial yields. Such sensitivity has been observed by Leskovar et al. [30] in Texas, USA, Zheng et al. [28] in northwestern China, Semida et al. [24] in Egypt, and Rop et al. [31] in Kenya. These studies observed reductions in bulb yield and size under water deficits. Compared with the bulb ripening stage, onions are more sensitive to soil water deficits at the bulbing [32] and vegetative growth [28] stages. Water restriction during the vegetative growth and bulbing stages result in the highest percentages of small size bulbs in Spain [33].

The crop response to deficit irrigation varies with location, stress patterns, cultivar, planting dates, and other factors [10], and it is thus important to determine the onion response to deficit irrigation for the particular conditions within a traditional Valencian crop rotation. The objective of this study was to determine the effects of RDI on the growth, plant water status, yield, bulb quality, IWUE, and crop profitability of onions cultivated under Mediterranean conditions.

\section{Materials and Methods}

\subsection{Experimental Site Conditions}

Two field experiments were carried out during the 2017 and 2018 seasons at the Cajamar Experimental Centre in Paiporta, Valencia, Spain (39.4175 N, 0.4184 W). These experiments were performed in two different plots to avoid soil diseases caused by repeated onion cultivation [26]. Both soil plots are deep with a medium (silt loam) texture and are classified as Petrocalcic Calcixerepts 
according to the USDA Soil Taxonomy [34]. The soils of the two plots are similar, being very slightly alkaline $(\mathrm{pH}=7.4-7.5)$ and highly fertile (organic matter $=1.9 \%-2.1 \%$, with highly available phosphorous (43-45 $\mathrm{mg} \mathrm{kg}^{-1}$; Olsen) and potassium (340-371 $\mathrm{mg} \mathrm{kg}^{-1}$; ammonium acetate extract) concentrations). Irrigation water was pumped from a well, with (on average) an electrical conductivity of $1.16 \mathrm{dS} \mathrm{m}^{-1}$ and a $77 \mathrm{mg} \mathrm{kg}^{-1} \mathrm{~N}-\mathrm{NO}_{3}{ }^{-}$content.

According to the Papadakis agro-climatic classification [35], the climate is subtropical Mediterranean ( $\mathrm{Su}, \mathrm{Me}$ ) with hot dry summers and an average annual rainfall of approximately $450 \mathrm{~mm}$, irregularly distributed throughout the year, falling mostly during the autumn and at the end of winter/beginning of spring. Figure 1 shows the most significant climatological data of the growing seasons.

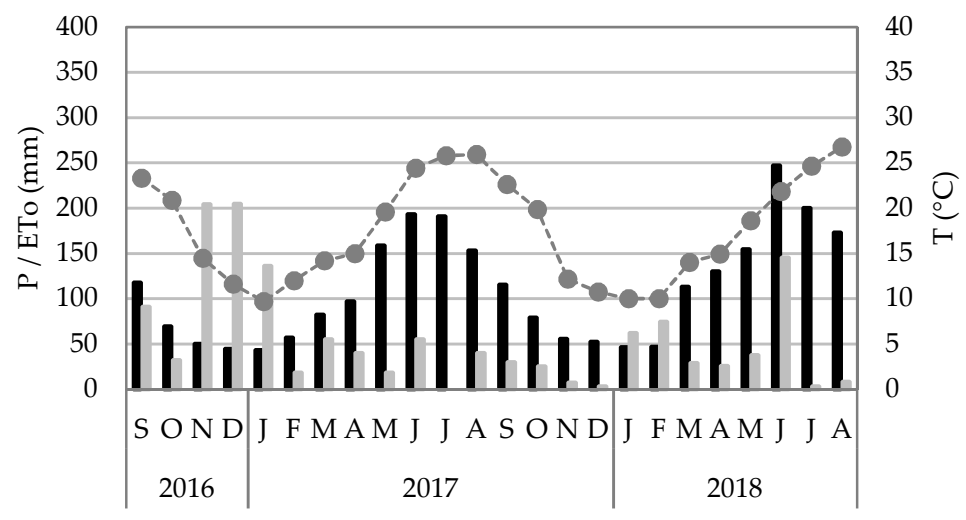

Figure 1. Monthly precipitation ( $\mathrm{P}, \mathrm{mm}$; gray vertical bars), reference evapotranspiration (ETo, $\mathrm{mm}$; black vertical bars), and average temperature $\left(\mathrm{T},{ }^{\circ} \mathrm{C}\right)$ during the two growing seasons.

\subsection{Plant Material and Growth Conditions}

The onion 'Hamaemi' was used in these experiments. This onion produces medium-size bulbs, with a straw yellow colour and flattened globose shapes. This cultivar is suitable for producing tender onions, which are appreciated by the local market, and it is well adapted to the soil and climatic conditions in the area [36].

Seeds were sowed on 20 September 2016 and 15 September 2017, in 448 cell flexible polyethylene trays in a peat moss based substrate (70\% blonde and 30\% dark; Pindstrup Mosebrug S.A.E., Sotopalacios, Spain) and placed in a Venlo-type greenhouse. Seedlings were transplanted to an open field when the plants had reached the two-leaf stage on 4 November 2016 and 30 October 2017. The transplantation was accomplished with a four-row onion transplanter (Minoru, Fukui, Japan), with plant and row spacings of $0.11 \mathrm{~m} \times 0.25 \mathrm{~m}$ and with four plant rows per bed. The top of the flat raised bed was $0.90 \mathrm{~m}$ wide (the distance from the bed centre-to-centre was $1.20 \mathrm{~m}$ ). The flat raised bed had a length of $7.25 \mathrm{~m}$ and a height of $0.15 \mathrm{~m}$, with north-south orientation. Each experimental plot consisted of a bed $\left(8.7 \mathrm{~m}^{2}\right.$ and 264 plants). The incorporation of nutrients (200-100-250 $\mathrm{kg} \mathrm{ha}^{-1} \mathrm{~N}-\mathrm{P}_{2} \mathrm{O}_{5}-\mathrm{K}_{2} \mathrm{O}$ ) was performed by fertigation with a nutrient solution based on the Sonneveld and Straverd [37] solution, following the criteria described by Miguel [38].

\subsection{Deficit Irrigation Strategies and Growth Stages}

The onion growth period was divided into four stages as follows: (1) initial stage, from transplanting to plant establishment; (2) vegetative growth stage, from plant establishment to when the bulbing ratio (bulb diameter/pseudostem diameter; periodically measured from three plants per plot) reached the value of 1.7 (intermediate value between the thresholds considered by Miguel [38] (1.5) and Leskovar et al. [30] (2.0) and Brewster [27] (2.0)); (3) bulbing stage, from the previous stage until most of the bulbs reach "full size" (approximately $70 \mathrm{~mm}$ in diameter, according to previous experiences with the cultivar in the Experimental Centre [36]); and (4) bulb ripening stage, from the 
previous stage until the harvest (two weeks after $50 \%$ of the leaves were bent over by the pseudostems). These four growth stages coincide with those defined by Allen et al. [39]: (1) initial stage, (2) growth development stage, (3) mid-season stage, and (4) late-season stage. During the initial period, all plants were irrigated without restrictions to ensure correct plant establishment. Different irrigation strategies were then initiated.

The experiments, carried out for two growing seasons (GS), compared seven irrigation strategies (IS). The analysed IS were as follows: T1, the application of full irrigation $(100 \%$ of the irrigation water requirements (IWR)) during the entire crop cycle; T2, T3, and T4, reduction of the irrigation water applied (IWA) to 75\% of the IWR during stages 2, 3, and 4, respectively; and T5, T6, and T7, reduction of the water applied to $50 \%$ of the IWR, at the same respective stages. Table 1 shows the duration and IWA of each growth stage. Initially, all the treatments were irrigated with 28 and $37 \mathrm{~mm}$ in 2017 and 2018, respectively, to ensure adequate plant establishment.

Table 1. Duration (days) and irrigation water applied ( $\mathrm{mm}$ ) at vegetative growth (2), bulbing (3), and bulb ripening (4) stages in each irrigation strategy (T1-T7) during the 2017 (4 November-27 April) and 2018 (30 October-30 April) growing seasons (GS).

\begin{tabular}{cccccccccc}
\hline \multirow{2}{*}{ GS } & \multirow{2}{*}{ Stages } & \multirow{2}{*}{ Days } & \multicolumn{7}{c}{ Irrigation Water Applied (mm) } \\
\cline { 3 - 10 } & & & T1 & T2 & T3 & T4 & T5 & T6 & T7 \\
\hline \multirow{3}{*}{2017} & 2 & 84 & 17 & 12 & 17 & 17 & 8 & 17 & 17 \\
& 3 & 43 & 70 & 70 & 52 & 70 & 70 & 35 & 70 \\
& 4 & 37 & 80 & 80 & 80 & 60 & 80 & 80 & 40 \\
\hline \multirow{2}{*}{2018} & Total & 164 & 167 & 162 & 149 & 147 & 158 & 131 & 127 \\
& 2 & 87 & 131 & 98 & 131 & 131 & 65 & 131 & 131 \\
& 3 & 39 & 61 & 61 & 46 & 61 & 61 & 31 & 61 \\
& 4 & 43 & 139 & 139 & 139 & 104 & 139 & 139 & 69 \\
& Total & 169 & 331 & 298 & 316 & 296 & 265 & 300 & 262 \\
\hline
\end{tabular}

\subsection{Irrigation Scheduling and System}

The IWR values were determined using the following equation:

$$
\mathrm{IWR}=\frac{E T_{\mathrm{C}}-\mathrm{Pe}}{\mathrm{Ef}},
$$

where $\mathrm{ET}_{\mathrm{c}}(\mathrm{mm})$ is the crop evapotranspiration; $\mathrm{Pe}$ is the effective precipitation $(\mathrm{mm})$, determined from rainfall data using the method of the U.S. Bureau of Reclamation [40], as presented by Pascual-Seva et al. [41]; and Ef is the irrigation efficiency, being 0.95 (considering that the uniform distribution $=0.98$; deep percolation ratio $=0.97$; the leaching requirement is negligible, as has been stated for onion cultivars grown in the Experimental Centre).

The ETc $(\mathrm{mm})$ was calculated from the $\mathrm{ET}_{\mathrm{o}}$, and a single crop coefficient $\left(\mathrm{K}_{\mathrm{c}}\right)$ was proposed for local conditions by the IVIA [42], adapting the duration of each stage to the growing cycle (Table 1). The $\mathrm{K}_{\mathrm{c}}$ values used were $0.3,0.95$, and 0.8 , corresponding to the initial, mid-season, and late season stages, respectively.

$$
\mathrm{ET}_{\mathrm{c}}=\mathrm{ET}_{\mathrm{o}} \times \mathrm{K}_{\mathrm{c}}
$$

where $\mathrm{ET}_{\mathrm{o}}$ is the reference evapotranspiration and $\mathrm{K}_{\mathrm{c}}$ is the crop coefficient. The $\mathrm{ET}_{\mathrm{o}}$ was determined according to Allen et al. [39], as follows:

$$
\mathrm{ET}_{\mathrm{o}}=\mathrm{E}_{\mathrm{pan}} \times \mathrm{K}_{\mathrm{p}}
$$

where $\mathrm{E}_{\mathrm{pan}}\left(\mathrm{mm}\right.$ day $\left.^{-1}\right)$ is the evaporation from a class A pan installed adjacent to the experimental plot, and $\mathrm{K}_{\mathrm{p}}(0.815)$ is the pan coefficient determined according to Allen et al. [39]. 
The irrigation water was supplied by a double lateral line for each bed using a turbulent flow dripline (16 mm; AZUDRIP Compact; Sistema Azud S.A., Murcia, Spain) with emitters $\left(2.2 \mathrm{~L} \mathrm{~h}^{-1}\right.$ ) spaced $0.33 \mathrm{~m}$ apart. An irrigation controller programmer (NODE-100 single station controller, Hunter, CA, USA) was used to control the time of each irrigation event, and a water flow meter (MJ-SDC TYP E, NWM, Czech Republic) was installed in each IS to record the IWA.

\subsection{Volumetric Soil Water Content}

The volumetric soil water content $\left(\mathrm{VSWC} ; \mathrm{m}^{3} \mathrm{~m}^{-3}\right.$ ) was continuously monitored using $\mathrm{ECH}_{2} \mathrm{O}$ EC-5 capacitance sensors connected to an Em50 data logger using the $\mathrm{ECH}_{2} \mathrm{O}$ Utility software (Decagon Devices Inc., Pullman, WA, USA). Onions have shallow root systems, with most roots being concentrated in the upper $0.20 \mathrm{~m}$ of the soil; therefore, following the methodology described by Enciso et al. [43], in each treatment, one sensor was installed horizontally, at a depth of $0.15 \mathrm{~m}$, in the middle of the beds below a dripline and equidistant between two adjacent emitters. Additionally, for T1, another sensor was placed at a $0.25 \mathrm{~m}$ soil depth to verify that water losses at that depth were nearly negligible. The VSWC was measured and stored at $15 \mathrm{~min}$ intervals, and variations in the VSWC were used to determine the in situ field capacity (FC). To compare the VSWCs corresponding to the different IS and GS, their values are presented as the ratio of the VSWC compared with the VSWC at FC (\% FC). The irrigation events for all the IS began when the VSWC in T1 dropped to $80 \%$ of the FC, following the criteria used in prior experiments at the Experimental Centre, and lasted the time necessary for applying the corresponding IWA.

\subsection{Relative Water Content and Membrane Stability Index (MSI), Plant Growth, and Harvest Index}

The RWC and MSI were evaluated at the end of each growth stage. Leaf RWC was determined in fresh leaf discs of $2 \mathrm{~cm}$ diameter using the method developed by Hayat et al. [44], and was calculated using the following equation:

$$
\operatorname{RWC}(\%)=\frac{\mathrm{FW}-\mathrm{DW}}{\mathrm{TW}-\mathrm{DW}} * 100,
$$

where FW, DW, and TW are the disc fresh weight, dry weight, and turgor weight, respectively.

The MSI was determined using $0.2 \mathrm{~g}$ samples of fully expanded leaf tissue following the methodology described by Rady [45], and was calculated as follows:

$$
\operatorname{MSI}(\%)=\left(1-\frac{C_{1}}{C_{2}}\right) * 100,
$$

where $C_{1}$ is the electrical conductivity of the solution after the samples were heated at $40{ }^{\circ} \mathrm{C}$ in a water bath for $30 \mathrm{~min}$, and $\mathrm{C}_{2}$ is the electrical conductivity of the solution after the samples were boiled at $100{ }^{\circ} \mathrm{C}$ for $10 \mathrm{~min}$.

Three onion plants per plot were selected at harvest (two weeks after $50 \%$ of the leaves near the pseudostems were bent over, 27 and 30 April of 2017 and 2018) to measure the following plant growth parameters: plant height, leaf number per plant, bulb diameter, and height. The leaf chlorophyll index (SPAD) was measured at three points in three fully developed leaves from each plant using a SPAD-502 m leaf chlorophyll meter (Konica Minolta Sensing Inc., Tokyo, Japan). Thereafter, these plants were separated into leaves and bulbs and each part was weighed (fresh weight) with a precision analytical balance (Mettler Toledo AG204, Greifensee, Switzerland), and dried at $65^{\circ} \mathrm{C}$ in a forced-air oven (Selecta 297, Barcelona, Spain) until a constant weight was reached to obtain dry weights and bulb dry matter content. The harvest index (HI) was determined as the ratio of total yield (TY) to total biomass (leaves + bulbs) on a dry mass basis $\left(\mathrm{g} \mathrm{g}^{-1} ;[46]\right)$.

\subsection{Yield, Irrigation Water Use Efficiency and Yield Response Factor}

The yield components were determined from a $3 \mathrm{~m}$ length in the two central plant rows, leaving a plant row on each side of the bed to avoid marginal effects. The bulb yield was partitioned 
into marketable (MY) and non-marketable yield. The average bulb weight of MY was determined. The non-marketable yield was, in turn, classified according to the nature of blemishes, including small bulbs, bulbs with defects in shape, and bolting plants, in accordance with Leskovar et al. [30].

The IWUE was calculated as the ratio of MY (fresh mass; $\mathrm{kg} \mathrm{m}^{-2}$ ) to IWA $\left(\mathrm{m}^{3} \mathrm{~m}^{-2}\right.$; [47]). The yield response to water deficits $\left(\mathrm{K}_{\mathrm{y}}\right)$ during the growing season and at each growth stage were determined according to Doorenbos and Kassam [48] using the following equation:

$$
\left(1-\frac{Y_{a}}{Y_{m}}\right)=K_{y}\left(1-\frac{E T_{a}}{E T_{m}}\right)
$$

where $Y_{a}$ and $Y_{m}$ are the actual MY (corresponding to the different RDI strategies at each stage) and maximum MY (fully irrigated plants), respectively; $\mathrm{ET}_{\mathrm{a}}$ and $\mathrm{ET}_{\mathrm{m}}$ are the actual (RDI) and maximum (full irrigated) ET (mm), respectively; and $\mathrm{K}_{\mathrm{y}}$ is the yield response factor, which was obtained by lineal regression for each stage. $\mathrm{ET}_{\mathrm{a}}$ and $\mathrm{ET}_{\mathrm{m}}$ were calculated as $\mathrm{ET}=\mathrm{IWA}+\mathrm{Pe}$, considering both the drainage and the variations in volumetric soil water content to be negligible.

\subsection{Onion Bulb Quality Traits}

Three representative (in size and shape) marketable bulbs per plot were used to determine the bulb size (height and diameter) and shape (diameter/height ratio). Then, these bulbs were used to determine the external bulb firmness using a digital penetrometer with an $8 \mathrm{~mm}$ diameter tip (Penefel DFT 14, Agro Technologies, Forges les Eaux, France). Then, the bulbs were liquefied with a domestic blender to obtain their juice, which was filtered. The soluble solids content (SSC, ${ }^{\circ}$ Brix) was determined from the bulb juice using a digital refractometer (PAL-1, Atago, Tokyo, Japan). Acidity (grams of citric acid/100 g FW) was determined by titration with $0.1 \mathrm{M} \mathrm{NaOH}$. The maturity index (MI) was calculated as the ratio of SSC ( ${ }^{\circ}$ Brix) and acidity (g citric acid $\left.100 \mathrm{~g}^{-1} \mathrm{FW}\right)$.

\subsection{Crop Profitability}

The determination of the profitability of the RDI, as presented in Pascual-Seva et al. [49], under the conditions of this study can help to make decisions that reduce water consumption. The gross revenue and water economic value were determined, taking into account the MY and the IWUE obtained in this study, as well as the average price of the onion bulbs over the previous three years $\left(0.21 € \mathrm{~kg}^{-1}[50]\right.$.

\subsection{Experimental Design and Statistical Analysis}

The experiment was performed using a randomized complete block design with three replicates. The results for the different parameters were evaluated by analysis of variance (ANOVA) using Statgraphics Centurion XVII [51]. Percentage data were arcsin transformed before analysis. Least significant differences (LSD) at a 0.05 probability level were used as the mean separation test. MY and IWUE were related with IWA using Statgraphics Centurion XVII [51].

\section{Results}

The rainfall registered in the 2017 season was higher $(618 \mathrm{~mm})$ than in $2018(203 \mathrm{~mm})$, and most of the rainfall during 2017 occurred at the vegetative growth stage, with lower values of rainfall occurring at the bulb ripening stage in both GS (Figure 1). These facts are responsible for the significant interactive effect $(p \leq 0.01 / 0.05)$ between the IS and GS on many of the studied parameters. When the GS * IS interaction was not significant $(p \leq 0.05)$, the mean values of the two factors were analysed separately, but when the interaction was significant $(p \leq 0.05)$, the two factors were analysed jointly.

\subsection{Growth Stages and Irrigation Water Applied}

The total crop cycle period (including the initial period) was shorter in 2017 than in 2018, lasting 175 and 183 days, respectively. The total pan evaporation and $\mathrm{ET}_{\mathrm{o}}$ during the growing season were 
lower in 2017 (334 and $272 \mathrm{~mm}$, respectively) than in 2018 (576 and $469 \mathrm{~mm}$, respectively). The values of $\mathrm{P}_{\mathrm{e}}$ during the growing season were higher during $2017(387 \mathrm{~mm})$ than during $2018(148 \mathrm{~mm})$. In 2017, there were 10 irrigation events, while in 2018, the number of irrigation events increased to 27 . The IWA values during the different irrigation periods ranged from $127 \mathrm{~mm}$ (T7) to $167 \mathrm{~mm}$ (T1) in 2017 and from $262 \mathrm{~mm}$ (T7) to $331 \mathrm{~mm}$ (T1) in 2018 (Table 1).

\subsection{Volumetric Soil Water Content}

The VSWC for the different IS and GS at $0.15 \mathrm{~m}$ depth (in addition, $0.25 \mathrm{~m}$ depth in T1), as well as the daily rainfall during both GS, are presented in Figure 2. The high rainfall in 2017 led to a high VSWC for all the IS, being higher in 2017 (on average, $92.0 \%$ of FC) than in 2018 (on average, $86.4 \%$ of FC). Therefore, during 2017, there were no considerable differences in the VSWC among the different IS; however, the average VSWC in 2018 at a $0.15 \mathrm{~m}$ depth ranged between $87.6 \%$ of the FC for T1 and $84.7 \%$ of the FC for T6, and the VSWC decreased slightly over time. Lower variations in the VSWC at a $0.25 \mathrm{~m}$ depth were recorded in 2018 than in 2017.
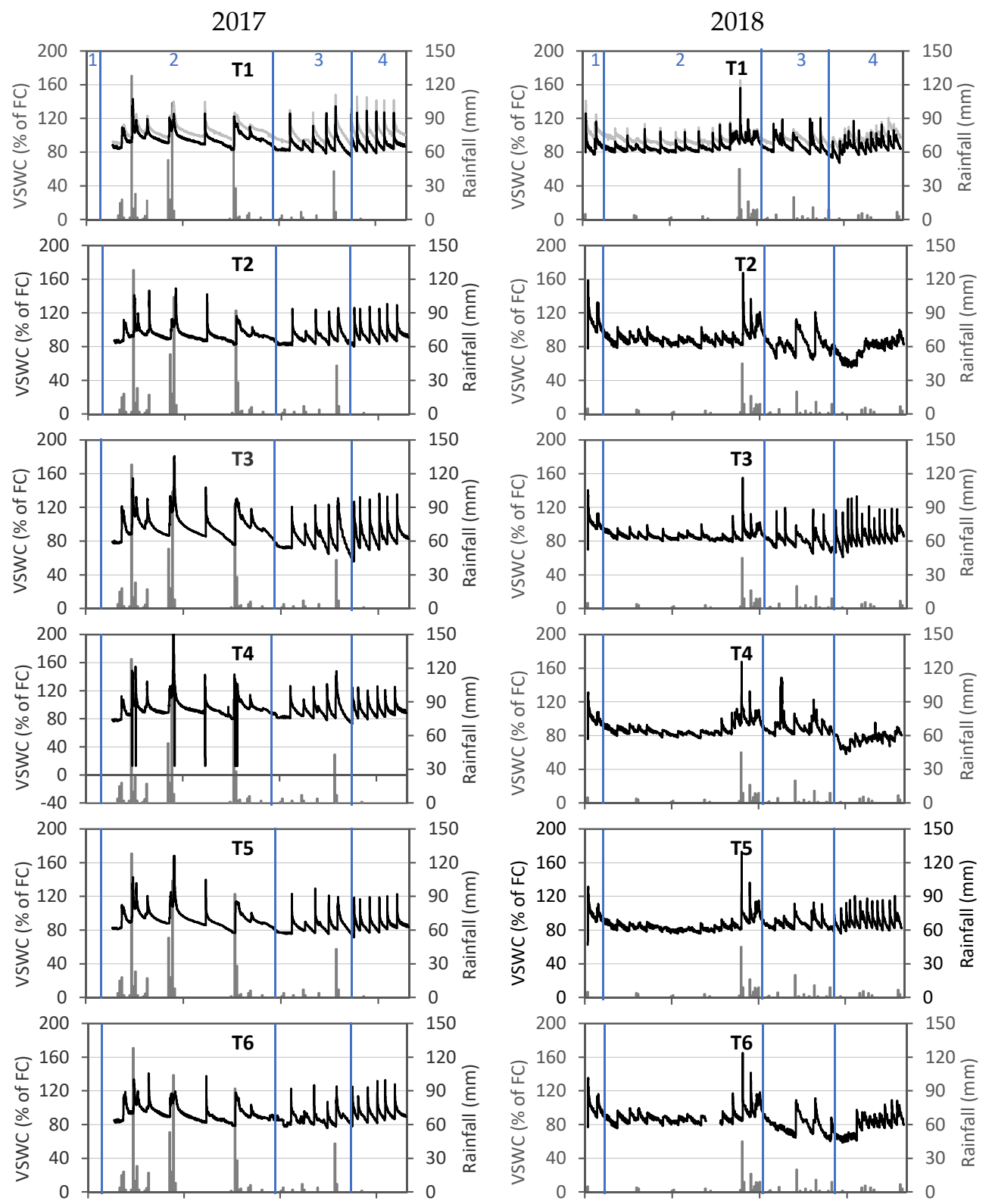

Figure 2. Cont. 

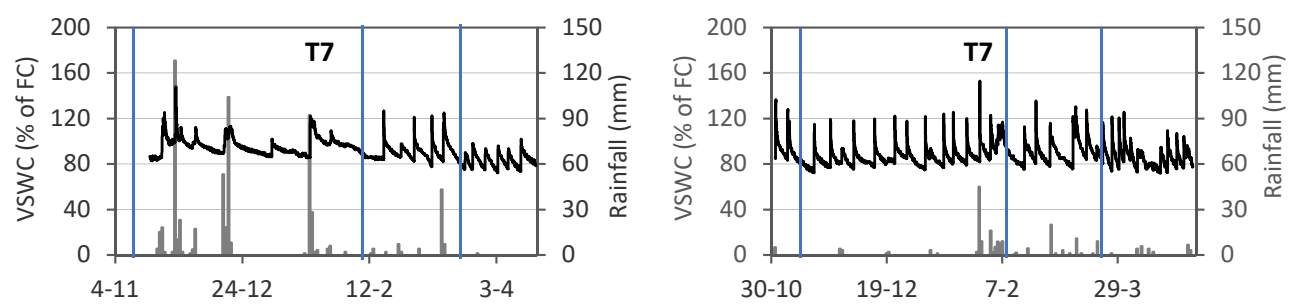

Figure 2. Volumetric soil water content (VSWC in percentage of field capacity $(\mathrm{FC})-15 \mathrm{~cm},-25 \mathrm{~cm}$ ) for each irrigation strategy and daily rainfall during the two growing seasons. Crop growth stages: (1) initial; (2) vegetative growth; (3) bulbing; and (4) bulb ripening.

\subsection{Relative Water Content, Membrane Stability Index, Onion Growth, and Harvest Index}

The RWC and MSI were affected $(p \leq 0.05 / 0.01)$ by the GS, and both parameters at each analysed time in 2017 were higher than in 2018 (Table 2). The RWC and MSI at establishment were not affected by the IS ( $p>0.05$; data not shown), but at the end of the vegetative growth (stage 2 ), both parameters were affected $(p \leq 0.01)$ by the GS, IS, and their interaction (Table 2$)$. There were no differences between the IS in 2017, while in 2018, T2 and T5 led to lower values $(p \leq 0.01$; Table 3). At the bulbing and bulb ripening stages, the interactions were not significant (Table 2) for the RWC or MSI, and these lower values corresponded to the strategies of severe water restriction $(50 \%$ IWR) in the corresponding stages (T6, T7).

Table 2. Effects of the growing season and the irrigation strategy on the relative water content (RWC) and membrane stability index (MSI) at the end of the vegetative growth (2), bulbing (3), and bulbing ripening (4) stages.

\begin{tabular}{ccccccc}
\hline & \multicolumn{3}{c}{ RWC (\%) } & \multicolumn{3}{c}{ MSI (\%) } \\
\cline { 2 - 7 } & $\mathbf{2}$ & $\mathbf{3}$ & $\mathbf{4}$ & $\mathbf{2}$ & $\mathbf{3}$ & $\mathbf{4}$ \\
\hline Growing Season (GS) & & & & & & \\
2017 & $79.7 \mathrm{a}$ & $81.8 \mathrm{a}$ & $82.6 \mathrm{a}$ & $70.1 \mathrm{a}$ & $71.5 \mathrm{a}$ & $69.4 \mathrm{a}$ \\
2018 & $76.8 \mathrm{~b}$ & $79.8 \mathrm{~b}$ & $80.1 \mathrm{~b}$ & $61.7 \mathrm{~b}$ & $59.7 \mathrm{~b}$ & $58.9 \mathrm{~b}$ \\
LSD & 1.5 & 2.1 & 1.9 & 1.4 & 1.7 & 1.9 \\
Irrigation Strategies (IS) & & & & & & \\
T1 & $79.4 \mathrm{a}$ & $81.8 \mathrm{ab}$ & $83.9 \mathrm{a}$ & $67.2 \mathrm{a}$ & $68.0 \mathrm{a}$ & $67.6 \mathrm{a}$ \\
T2 & $76.1 \mathrm{bc}$ & $81.4 \mathrm{abc}$ & $82.8 \mathrm{a}$ & $63.6 \mathrm{bc}$ & $65.2 \mathrm{ab}$ & $65.1 \mathrm{ab}$ \\
T3 & $78.5 \mathrm{ab}$ & $78.9 \mathrm{bc}$ & $80.3 \mathrm{ab}$ & $67.0 \mathrm{a}$ & $65.9 \mathrm{ab}$ & $65.5 \mathrm{ab}$ \\
T4 & $79.2 \mathrm{a}$ & $83.9 \mathrm{a}$ & $82.7 \mathrm{a}$ & $67.9 \mathrm{a}$ & $67.0 \mathrm{a}$ & $64.9 \mathrm{ab}$ \\
T5 & $74.9 \mathrm{c}$ & $81.6 \mathrm{ab}$ & $80.6 \mathrm{ab}$ & $63.0 \mathrm{c}$ & $63.7 \mathrm{c}$ & $62.6 \mathrm{bc}$ \\
T6 & $79.7 \mathrm{a}$ & $77.7 \mathrm{c}$ & $80.8 \mathrm{ab}$ & $65.7 \mathrm{ab}$ & $63.2 \mathrm{c}$ & $62.5 \mathrm{bc}$ \\
T7 & $80.1 \mathrm{a}$ & $80.5 \mathrm{abc}$ & $78.5 \mathrm{~b}$ & $67.0 \mathrm{a}$ & $66.0 \mathrm{ab}$ & $61.0 \mathrm{c}$ \\
LSD & 2.9 & 3.8 & 3.6 & 2.5 & 3.23 & 3.58 \\
\hline ANOVA (df) & & & $\% \mathrm{sum}$ of squares & & \\
\hline GS (1) & $14.2 * *$ & $7.1 \mathrm{~ns}$ & $13.8^{*}$ & $64.6 * *$ & $79.9 * *$ & $69.0 * *$ \\
IS (6) & $23.9 * *$ & $25.3 *$ & $27.2 *$ & $11.3 * *$ & $5.8 *$ & $10.9 *$ \\
GS*IS (6) & $34.5 * *$ & $17.9 \mathrm{~ns}$ & $2.8 \mathrm{~ns}$ & $13.1 * *$ & $3.0 \mathrm{~ns}$ & $4.7 \mathrm{~ns}$ \\
Residuals (28) & 27.4 & 49.6 & 56.1 & 11.0 & 11.3 & 15.5 \\
Standard deviation & 2.4 & 3.2 & 3.0 & 2.1 & 2.7 & 3.0 \\
\hline
\end{tabular}

df: degrees of freedom. Mean values followed by different lower-case letters in each column indicate significant differences at $p \leq 0.05$ using the least significant differences (LSD) test. ${ }^{* *}(*)$, indicate significant differences at $p \leq 0.01$ ( $p \leq 0.05)$. ns, indicates no significant difference. ANOVA, analysis of variance. 
Table 3. Growing season-irrigation strategy interaction for the relative water content (RWC) and membrane stability index (MSI) at the end of the vegetative growth, bulb dry weight (BDW), total yield (Yield), marketable yield (MY), and average bulb weight (ABW).

\begin{tabular}{|c|c|c|c|c|c|c|}
\hline & $\begin{array}{c}\text { RWC } \\
(\%)\end{array}$ & $\begin{array}{l}\text { MSI } \\
(\%)\end{array}$ & $\begin{array}{c}\text { BDW } \\
\left(\mathrm{kg} \mathrm{m}^{-2}\right)\end{array}$ & $\begin{array}{c}\text { Yield } \\
\left(\mathrm{kg} \mathrm{m}^{-2}\right)\end{array}$ & $\begin{array}{c}\mathrm{MY} \\
\left(\mathrm{kg} \mathrm{m}^{-2}\right)\end{array}$ & $\begin{array}{c}\text { ABW } \\
\text { (g bulb } \\
-1)\end{array}$ \\
\hline \multicolumn{7}{|l|}{2017} \\
\hline $\mathrm{T} 1$ & $79.6 \mathrm{a}$ & $68.9 \mathrm{a}$ & $0.44 \mathrm{~d}$ & $4.91 \mathrm{f}$ & $4.24 \mathrm{f}$ & $183.9 \mathrm{e}$ \\
\hline $\mathrm{T} 2$ & $80.5 \mathrm{a}$ & $68.9 \mathrm{a}$ & $0.40 \mathrm{~d}$ & $4.80 \mathrm{f}$ & $4.28 \mathrm{f}$ & $184.8 \mathrm{e}$ \\
\hline $\mathrm{T} 3$ & $78.6 \mathrm{a}$ & $69.4 \mathrm{a}$ & $0.38 \mathrm{~d}$ & $4.87 \mathrm{f}$ & $4.20 \mathrm{f}$ & $185.6 \mathrm{e}$ \\
\hline $\mathrm{T} 4$ & $78.9 \mathrm{a}$ & $71.5 \mathrm{a}$ & $0.46 \mathrm{~d}$ & $4.74 \mathrm{f}$ & $4.15 \mathrm{f}$ & $181.4 \mathrm{e}$ \\
\hline T5 & $80.2 \mathrm{a}$ & $70.8 \mathrm{a}$ & $0.43 \mathrm{~d}$ & $4.80 \mathrm{f}$ & $4.13 \mathrm{f}$ & $185.4 \mathrm{e}$ \\
\hline T6 & $79.4 \mathrm{a}$ & $70.8 \mathrm{a}$ & $0.38 \mathrm{~d}$ & $4.67 \mathrm{f}$ & $3.93 \mathrm{f}$ & $174.7 \mathrm{e}$ \\
\hline $\mathrm{T} 7$ & $80.5 \mathrm{a}$ & $70.7 \mathrm{a}$ & $0.38 \mathrm{~d}$ & $4.72 \mathrm{f}$ & $4.12 \mathrm{f}$ & $185.4 \mathrm{e}$ \\
\hline \multicolumn{7}{|l|}{2018} \\
\hline $\mathrm{T} 1$ & $79.2 \mathrm{a}$ & $65.5 \mathrm{~b}$ & $0.88 \mathrm{a}$ & $8.93 \mathrm{a}$ & $8.04 \mathrm{a}$ & $340.5 \mathrm{a}$ \\
\hline $\mathrm{T} 2$ & $71.7 \mathrm{~b}$ & $58.2 \mathrm{~d}$ & $0.78 \mathrm{~b}$ & 8.40 bc & $7.35 \mathrm{bc}$ & $318.0 \mathrm{bc}$ \\
\hline T3 & $78.5 \mathrm{a}$ & $64.7 \mathrm{~b}$ & $0.75 \mathrm{~b}$ & $8.74 \mathrm{ab}$ & $7.77 \mathrm{ab}$ & $327.1 \mathrm{a}$ \\
\hline $\mathrm{T} 4$ & $79.4 \mathrm{a}$ & $64.3 \mathrm{~b}$ & $0.76 \mathrm{~b}$ & $8.97 \mathrm{a}$ & $7.66 \mathrm{ab}$ & $327.0 \mathrm{ab}$ \\
\hline $\mathrm{T} 5$ & $69.5 \mathrm{~b}$ & $55.2 \mathrm{e}$ & $0.59 \mathrm{c}$ & $7.22 \mathrm{e}$ & $6.06 \mathrm{e}$ & $296.9 d$ \\
\hline $\mathrm{T} 6$ & $80.0 \mathrm{a}$ & $60.5 \mathrm{~cd}$ & $0.72 \mathrm{~b}$ & $7.66 \mathrm{de}$ & $6.55 \mathrm{de}$ & $303.0 \mathrm{~d}$ \\
\hline T7 & $79.6 \mathrm{a}$ & $63.3 \mathrm{bc}$ & $0.74 \mathrm{~b}$ & $7.99 \mathrm{~cd}$ & $7.03 \mathrm{~cd}$ & $310.4 \mathrm{~cd}$ \\
\hline LSD & 3.3 & 2.97 & 0.09 & 0.49 & 0.63 & 15.5 \\
\hline
\end{tabular}

Mean values followed by different lower-case letters in each column indicate significant differences at $p \leq 0.05$ using the LSD test.

The values of plant growth traits (except for SPAD; Table 4) were affected $(p \leq 0.01)$ by the GS, with lower values obtained in 2017 than in 2018, except for the bulbing ratio, which was higher in 2017. In both GS, the bulbing ratios usually increased during the crop cycle, being considered as a measure of bulb formation; the bulbing ratios reached their highest values at harvest. The data for the bulbing ratios at the end of vegetative growth are presented in Table 4, and they were not affected by the IS. The plant heights and the numbers of leaves per plant were not affected by the IS $(p>0.05$; Table 4); nevertheless, lower values were obtained for plants that were exposed to water stress during the vegetative growth stage (T2 and T5). The SPAD index was not affected ( $p \leq 0.05)$ by the GS nor by IS. Water restrictions negatively affected the production of biomass, for both the leaves (fresh and dry weight; $p \leq 0.05$, Table 4 ) and the bulbs (fresh $p \leq 0.05$, Table 5; dry $p \leq 0.01$, Table 4 ), with the greatest values (in these parameters) corresponding to full irrigation (T1) and moderate deficit irrigation during bulb ripening (T4). The bulb dry weights were affected by the IS only in $2018(p \leq 0.01)$, when the highest values were obtained for the fully irrigated plants (T1; $p \leq 0.05$; Table 3 ), reducing in value with the water deficit, and this phenomenon occurred to a greater extent with the severe deficit and in the earlier stages. Greater values of HI $(p \leq 0.05)$ were obtained in 2018 than in 2017 and were not affected by IS $(p>0.05)$. 
Table 4. Effects of the growing season and the irrigation strategy on the bulbing ratio at the end of stage 2, and on the plant height, leaf number per plant, leaf chlorophyll index (SPAD), leaf fresh weight (LFW), leaf dry weight (LDW), bulb dry weight (BDW), and harvest index (HI) at harvesting.

\begin{tabular}{|c|c|c|c|c|c|c|c|c|}
\hline & Bulbing & Plant & Leaf & SPAD & LFW & LDW & BDW & HI \\
\hline & $\begin{array}{c}\text { Ratio } \\
(-)\end{array}$ & $\begin{array}{l}\text { Height } \\
\text { (cm) }\end{array}$ & Number & $(-)$ & $\left(\mathrm{kg} \mathrm{m}^{-2}\right)$ & $\left(\mathrm{kg} \mathrm{m}^{-2}\right)$ & $\left(\mathrm{kg} \mathrm{m}^{-2}\right)$ & $(-)$ \\
\hline \multicolumn{9}{|c|}{ Growing Season (GS) } \\
\hline 2017 & $1.79 \mathrm{a}$ & $47.14 \mathrm{~b}$ & $6.71 \mathrm{~b}$ & 62.95 & $0.67 \mathrm{~b}$ & $0.085 \mathrm{~b}$ & $0.41 \mathrm{~b}$ & $0.83 \mathrm{~b}$ \\
\hline 2018 & $1.63 \mathrm{~b}$ & $57.78 \mathrm{a}$ & $7.40 \mathrm{a}$ & 64.56 & $1.20 \mathrm{a}$ & $0.119 \mathrm{a}$ & $0.75 \mathrm{a}$ & $0.86 \mathrm{a}$ \\
\hline LSD & 0.09 & 1.72 & 0.27 & 2.20 & 0.07 & 0.008 & 0.04 & 0.01 \\
\hline \multicolumn{9}{|c|}{ Irrigation Strategies (IS) } \\
\hline $\mathrm{T} 1$ & 1.71 & 53.94 & 7.22 & 62.60 & $1.04 \mathrm{a}$ & $0.121 \mathrm{a}$ & $0.66 \mathrm{a}$ & 0.84 \\
\hline $\mathrm{T} 2$ & 1.75 & 50.33 & 6.94 & 65.14 & $0.90 \mathrm{bc}$ & $0.100 \mathrm{~b}$ & $0.59 \mathrm{~b}$ & 0.85 \\
\hline $\mathrm{T} 3$ & 1.68 & 52.39 & 7.11 & 64.67 & $0.96 \mathrm{abc}$ & $0.095 \mathrm{~b}$ & $0.57 \mathrm{bc}$ & 0.85 \\
\hline $\mathrm{T} 4$ & 1.74 & 53.89 & 7.17 & 65.62 & $0.99 \mathrm{ab}$ & $0.105 \mathrm{ab}$ & $0.61 \mathrm{ab}$ & 0.85 \\
\hline T5 & 1.64 & 50.72 & 6.78 & 63.86 & $0.86 \mathrm{bc}$ & $0.099 \mathrm{~b}$ & $0.51 \mathrm{c}$ & 0.84 \\
\hline T6 & 1.73 & 52.33 & 7.06 & 63.11 & $0.89 \mathrm{bc}$ & $0.096 \mathrm{~b}$ & $0.55 \mathrm{bc}$ & 0.85 \\
\hline $\mathrm{T} 7$ & 1.74 & 53.61 & 7.11 & 61.28 & $0.89 \mathrm{bc}$ & $0.098 \mathrm{~b}$ & $0.56 \mathrm{bc}$ & 0.84 \\
\hline LSD & 0.17 & 3.21 & 0.50 & 4.11 & 0.13 & 0.016 & 0.07 & 0.02 \\
\hline ANOVA (df) & \multicolumn{8}{|c|}{$\%$ sum of squares } \\
\hline GS (1) & $9.2 * *$ & $54.2 * *$ & $17.3^{* *}$ & $1.7 \mathrm{~ns}$ & $65.1 * *$ & $31.2 * *$ & $69.2 * *$ & $22.1 * *$ \\
\hline IS (6) & $2.0 \mathrm{~ns}$ & $3.6 \mathrm{~ns}$ & $2.9 \mathrm{~ns}$ & $5.3 \mathrm{~ns}$ & $3.2 *$ & $7.4 *$ & $4.7 * *$ & $2.7 \mathrm{~ns}$ \\
\hline GS*IS (6) & $6.1 \mathrm{~ns}$ & $1.8 \mathrm{~ns}$ & $3.6 \mathrm{~ns}$ & $3.9 \mathrm{~ns}$ & $2.1 \mathrm{~ns}$ & $1.4 \mathrm{~ns}$ & $3.9^{* *}$ & $6.4 \mathrm{~ns}$ \\
\hline Residuals (112) & 82.8 & 40.4 & 76.2 & 89.2 & 29.6 & 60.0 & 22.2 & 68.8 \\
\hline Standard deviation & 0.3 & 4.9 & 0.8 & 6.2 & 0.2 & 0.0 & 0.1 & 0.0 \\
\hline
\end{tabular}

Table 5. Effects of the growing season and the irrigation strategy on the total yield (Yield); marketable yield; average bulb weight (ABW); non-marketable yield and its partitioning in small, deformed, and bolting bulbs; and irrigation water use efficiency (IWUE).

\begin{tabular}{|c|c|c|c|c|c|c|c|c|}
\hline & \multirow{2}{*}{$\begin{array}{c}\text { Yield } \\
\left(\mathrm{kg} \mathrm{m}^{-2}\right)\end{array}$} & \multicolumn{2}{|c|}{ Marketable Yield } & \multicolumn{4}{|c|}{ Non-Marketable Yield (\% of Yield) } & \multirow{2}{*}{$\begin{array}{c}\text { IWUE } \\
\left(\mathrm{kg} \mathrm{m}^{-3}\right)\end{array}$} \\
\hline & & $\left(\mathrm{kg} \mathrm{m}^{-2}\right)$ & ABW (g bulb $\left.{ }^{-1}\right)$ & Total & Small & Deformed & Bolting & \\
\hline \multicolumn{9}{|l|}{ Growing Season (GS) } \\
\hline 2017 & $4.79 \mathrm{~b}$ & $4.15 \mathrm{~b}$ & $183.0 \mathrm{~b}$ & 13.3 & $3.0 \mathrm{~b}$ & $0.8 \mathrm{~b}$ & $9.5 \mathrm{a}$ & $28.15 \mathrm{a}$ \\
\hline 2018 & $8.27 \mathrm{a}$ & $7.21 \mathrm{a}$ & $317.6 \mathrm{a}$ & 13.0 & $8.3 \mathrm{a}$ & $1.7 \mathrm{a}$ & $3.0 \mathrm{~b}$ & $24.42 \mathrm{~b}$ \\
\hline LSD & 0.22 & 0.29 & 7.04 & 2.6 & 1.7 & 0.9 & 2.2 & 1.20 \\
\hline \multicolumn{9}{|l|}{ Irrigation Strategies (IS) } \\
\hline $\mathrm{T} 1$ & $6.92 \mathrm{a}$ & $6.14 \mathrm{a}$ & $262.2 \mathrm{a}$ & 11.7 & 4.4 & 1.3 & 6.1 & $24.85 \mathrm{bc}$ \\
\hline $\mathrm{T} 2$ & $6.60 \mathrm{ab}$ & $5.82 \mathrm{ab}$ & 251.4 abcd & 11.5 & 4.1 & 1.7 & 5.8 & $25.58 \mathrm{bc}$ \\
\hline $\mathrm{T} 3$ & $6.80 \mathrm{a}$ & $5.99 \mathrm{ab}$ & $256.3 \mathrm{ab}$ & 12.5 & 4.7 & 0.8 & 7.1 & $26.43 \mathrm{bc}$ \\
\hline $\mathrm{T} 4$ & $6.86 \mathrm{a}$ & $5.91 \mathrm{ab}$ & $254.2 \mathrm{abc}$ & 13.6 & 5. 6 & 1.8 & 6.3 & $27.07 \mathrm{~b}$ \\
\hline T5 & $6.01 \mathrm{c}$ & $5.10 \mathrm{c}$ & $241.1 \mathrm{~cd}$ & 14.9 & 8.4 & 1.7 & 4.8 & $24.49 c$ \\
\hline T6 & $6.17 c$ & $5.24 \mathrm{c}$ & $238.8 \mathrm{~d}$ & 15.4 & 6.5 & 1.0 & 7.9 & $25.88 \mathrm{bc}$ \\
\hline $\mathrm{T} 7$ & $6.36 \mathrm{bc}$ & $5.58 \mathrm{bc}$ & $247.9 \mathrm{bcd}$ & 12.5 & 5.9 & 0.8 & 5.9 & 29.70 a \\
\hline LSD & 0.41 & 0.53 & 13.17 & 4.9 & 3.2 & 1.7 & 4.0 & 2.25 \\
\hline ANOVA (df) & \multicolumn{8}{|c|}{$\%$ sum of squares } \\
\hline GS (1) & 91.6. ** & $86.8^{* *}$ & $96.0 * *$ & $0.1 \mathrm{~ns}$ & $46.8^{* *}$ & $11.7^{*}$ & $52.5^{* *}$ & $35.6^{* *}$ \\
\hline IS (6) & $3.3^{* *}$ & $4.9^{* *}$ & $1.3^{*}$ & $13.9 \mathrm{~ns}$ & $13.3 \mathrm{~ns}$ & $8.7 \mathrm{~ns}$ & $4.2 \mathrm{~ns}$ & $26.7^{* *}$ \\
\hline GS*IS (6) & $2.6^{* *}$ & $3.3^{*}$ & $1.0^{*}$ & $8.1 \mathrm{~ns}$ & $6.9 \mathrm{~ns}$ & $3.6 \mathrm{~ns}$ & $4.2 \mathrm{~ns}$ & $12.9 \mathrm{~ns}$ \\
\hline Residuals (28) & 2.5 & 5.0 & 1.8 & 77.9 & 33.0 & 75.9 & 39.0 & 24.7 \\
\hline Standard deviation & 0.3 & 0.6 & 11.1 & 4.1 & 2.7 & 1.5 & 3.4 & 1.9 \\
\hline
\end{tabular}

df: degrees of freedom. Mean values followed by different lower-case letters in each column indicate significant differences at $p \leq 0.05$ using the LSD test. ${ }^{* *}\left({ }^{*}\right)$, indicate significant differences at $p \leq 0.01(p \leq 0.05)$. ns, indicates no significant differences.

\subsection{Yield, Irrigation Water Use Efficiency and Yield Response Factor}

The GS had an important impact on yield (representing $92 \%$ and $87 \%$ of the sum of squares of yield and MY, respectively, Table 5). The MY losses corresponding to the most restricted strategies 
at the vegetative growth (on average, $17 \%$ for T5) and bulbing (15\% for T6) stages were greater than those obtained when the restriction was applied at the bulb ripening ( $9 \%$ for T7) stage. Yields and MY obtained in 2017 were lower than those in 2018 ( $p \leq 0.05)$, not differing between IS. In 2018, lower yields and MY were obtained with 50\% IWR reduction, when it was applied both in the vegetative growth (T5) and bulbing stages (T6; Table 3). The MY accounted (on average) for $87 \%$ of the yield; this MY proportion was not affected by the GS, IS, or their interaction (data of non-marketable yield shown in Table 5). The growing season had a greater influence on average bulb weight (ABW; $96 \%$ of the sum of squares) than IS (1.3\%) and their interaction (1\%); the bulbs obtained in 2017 were heavier than those in 2018, with no IS differences. However, in 2018, ABW was reduced with the water deficit $(p \leq 0.05)$, and this phenomenon occurred to a greater extent with the severe deficit (Table 3). In 2017, there was a higher $(p \leq 0.01)$ incidence of bolting bulbs, and a lower number of small bulbs $(p \leq 0.01)$ and bulbs with shape defects $(p \leq 0.05)$ than in 2018 .

IWUE was affected by GS and by IS ( $p \leq 0.01$; Table 5), with the highest values obtained in 2017, which corresponded to the lowest IWR. For IS, the highest average value $(p \leq 0.05)$ was obtained with the severe water shortage at the bulb ripening stage $\left(29.7 \mathrm{~kg} \mathrm{~m}^{-3}\right.$; T7) and was also related to the lowest IWA (127 mm for 2017 and $262 \mathrm{~mm}$ for 2018). The lowest IWUE value was obtained with the severe water shortage at the vegetative growth stage $\left(24.5 \mathrm{~kg} \mathrm{~m}^{-3} ; \mathrm{T} 5\right)$, as a consequence of the lowest MY obtained with this strategy $\left(5.1 \mathrm{~kg} \mathrm{~m}^{-2}\right)$.

Considering separately the different stages when water restrictions were applied, the MY $\left(\mathrm{kg} \mathrm{m}^{-2}\right)$ increased linearly $(p \leq 0.01)$ with increasing IWA $(\mathrm{mm})$, following these equations: vegetative growth: $\mathrm{MY}=0.57+0.022^{*} \mathrm{IWA}(\mathrm{r}=0.98 ; p \leq 0.01)$; bulbing: $\mathrm{MY}=1.11+0.020 * \operatorname{IWA}(\mathrm{r}=0.95 ; p \leq 0.01)$; and bulb ripening: $\mathrm{MY}=1.03+0.022^{*} \mathrm{IWA}(\mathrm{r}=0.97 ; p \leq 0.01)$. IWUE decreased linearly with increasing IWA, following the equations corresponding to vegetative growth, bulbing, and bulb ripening: IWUE $=27.89-0.013^{*} \mathrm{IWA}(\mathrm{r}=-0.55 ; p \leq 0.01)$; IWUE $=31.79-0.026^{*} \mathrm{IWA}(\mathrm{r}=-0.71$; $p \leq 0.01)$; and IWUE $=32.81-0.025^{*} \operatorname{IWA}(\mathrm{r}=-0641 ; p \leq 0.01)$.

For $\mathrm{K}_{\mathrm{y}}$, three fitted linear regression equations $(p \leq 0.01$ and $\mathrm{r} \geq 0.91$ ) were obtained, considering the two GS together, with one for each stage of irrigation restriction. The obtained $\mathrm{K}_{\mathrm{y}}$ values were 1.66 , 1.75 , and 0.75 for the vegetative growth, bulbing, and bulb ripening stages, respectively.

\subsection{Onion Bulb Quality Traits}

The bulb size (diameter and height) was affected by the GS, IS, and their interaction $(p \leq 0.01$; Table 6). In general, the bulbs produced in 2017 were shorter and narrower than those produced in 2018. The interaction shows that the shortest bulbs in 2017 corresponded to T4 and T6, while in 2018, these were obtained with T5 (Table 7). The bulb shapes were influenced by the GS $(p \leq 0.01)$ and the GS-IS interaction ( $p \leq 0.05$; Table 6 ), in the sense that the bulbs obtained in 2018 were flatter than those in 2017, with the most elongated bulbs being those obtained with T6 in both years and with T4 in 2018 (Table 7).

The dry matter content and SSC were only affected by GS ( $p \leq 0.01)$, corresponding to the higher values in 2018, while the firmness was not affected $(p>0.05)$ by any factor. In contrast, acidity was affected, in addition to the GS, by IS and by their interaction. The bulbs obtained in 2018 were, in general, more acidic than those obtained in 2017.

As a consequence of the respective values of SSC and acidity, the MI was affected by GS ( $p \leq 0.01)$ and by IS ( $p \leq 0.01)$, corresponding the highest values to 2018, and in relation to IS, MI increased with water deficit, particularly when severe water restriction was applied at the bulb ripening stage (T7). 
Table 6. Effects of the growing season and the irrigation strategy on bulb characteristics: size (diameter (D) and height $(\mathrm{H})$, shape $(\mathrm{D} / \mathrm{H}))$; dry matter content (DMC); firmness; soluble solid content (SSC); acidity; and maturity index (MI).

\begin{tabular}{|c|c|c|c|c|c|c|c|c|}
\hline & $\mathrm{D}(\mathrm{mm})$ & $\mathbf{H}(\mathbf{m m})$ & $\mathrm{D} / \mathrm{H}$ & $\begin{array}{c}\text { DMC } \\
(\%)\end{array}$ & $\begin{array}{l}\text { Firmness } \\
(\mathrm{N})\end{array}$ & $\begin{array}{c}\text { SSC } \\
\left({ }^{\circ} \text { Brix }\right)\end{array}$ & $\begin{array}{c}\text { Acidity } \\
(\%)\end{array}$ & MI \\
\hline \multicolumn{9}{|l|}{$\begin{array}{c}\text { Growing Season } \\
\text { (GS) }\end{array}$} \\
\hline 2017 & $74.4 \mathrm{~b}$ & $71.1 \mathrm{~b}$ & $1.05 \mathrm{~b}$ & $6.2 \mathrm{~b}$ & 27.4 & $5.20 \mathrm{~b}$ & $0.076 \mathrm{~b}$ & $68.9 \mathrm{~b}$ \\
\hline 2018 & 88.7 a & $72.1 \mathrm{a}$ & $1.23 \mathrm{a}$ & $8.2 \mathrm{a}$ & 27.6 & $7.49 \mathrm{a}$ & $0.091 \mathrm{a}$ & $83.5 \mathrm{a}$ \\
\hline LSD & 1.1 & 1.2 & 0.02 & 0.52 & 2.0 & 0.39 & 0.004 & 6.0 \\
\hline \multicolumn{9}{|l|}{$\begin{array}{l}\text { Irrigation Strategies } \\
\text { (IS) }\end{array}$} \\
\hline $\mathrm{T} 1$ & $83.9 \mathrm{a}$ & $73.0 \mathrm{a}$ & 1.15 & 7.2 & 28.1 & 6.37 & $0.094 \mathrm{a}$ & $67.4 \mathrm{c}$ \\
\hline $\mathrm{T} 2$ & $81.1 \mathrm{~b}$ & $71.9 \mathrm{ab}$ & 1.13 & 7.0 & 26.4 & 6.30 & $0.085 \mathrm{~b}$ & $74.4 \mathrm{bc}$ \\
\hline T3 & $82.2 \mathrm{ab}$ & $72.4 \mathrm{ab}$ & 1.14 & 7.9 & 27.9 & 6.55 & $0.089 \mathrm{ab}$ & $72.9 \mathrm{bc}$ \\
\hline $\mathrm{T} 4$ & $82.4 \mathrm{ab}$ & $72.6 \mathrm{ab}$ & 1.13 & 6.7 & 26.4 & 6.25 & $0.082 \mathrm{bc}$ & $75.5 \mathrm{abc}$ \\
\hline $\mathrm{T} 5$ & $79.0 \mathrm{c}$ & $69.3 c$ & 1.15 & 7.3 & 27.5 & 6.17 & $0.082 \mathrm{bc}$ & $75.0 \mathrm{bc}$ \\
\hline T6 & 80.7 bc & $70.4 \mathrm{bc}$ & 1.15 & 7.0 & 27.0 & 6.22 & $0.076 \mathrm{c}$ & $81.6 \mathrm{ab}$ \\
\hline $\mathrm{T} 7$ & $81.6 \mathrm{~b}$ & $71.5 \mathrm{ab}$ & 1.14 & 7.3 & 29.2 & 6.55 & $0.077 \mathrm{c}$ & $86.6 \mathrm{a}$ \\
\hline LSD & 2.1 & 2.2 & 0.04 & 1.0 & 3.8 & 0.72 & 0.007 & 11.3 \\
\hline ANOVA (df) & \multicolumn{8}{|c|}{$\%$ sum of squares } \\
\hline GS (1) & $89.4^{* *}$ & $4.0 \mathrm{~ns}$ & $\begin{array}{c}88.4 \\
* *\end{array}$ & $59.8^{* *}$ & $0.1 \mathrm{~ns}$ & $81.8^{* *}$ & $44.0^{* *}$ & $32.8^{* *}$ \\
\hline IS (6) & $3.5^{* *}$ & $22.2 *$ & $0.4 \mathrm{~ns}$ & $7.6 \mathrm{~ns}$ & $10.7 \mathrm{~ns}$ & $1.3 \mathrm{~ns}$ & $25.5^{* *}$ & $20.1 *$ \\
\hline GS*IS (6) & $3.3^{* *}$ & $40.2^{* *}$ & $4.2 *$ & $6.6 \mathrm{~ns}$ & $4.7 \mathrm{~ns}$ & $1.6 \mathrm{~ns}$ & $12.2 *$ & $9.6 \mathrm{~ns}$ \\
\hline Residuals (28) & 3.8 & 33.6 & 7.1 & 26.0 & 84.5 & 15.4 & 18.3 & 37.5 \\
\hline Standard deviation & 1.8 & 1.8 & 0.0 & 0.8 & 3.2 & 0.6 & 0.0 & 9.6 \\
\hline
\end{tabular}

df: degrees of freedom (112 for D, H, and D/H). SD: standard deviation. Mean values followed by different lower-case letters in each column indicate significant differences at $p \leq 0.05$ using the LSD test. ${ }^{* *}\left({ }^{*}\right)$, indicate significant differences at $p \leq 0.01(p \leq 0.05)$. ns, indicates no significant difference.

Table 7. Growing season-irrigation strategy interaction for bulb characteristics: size (diameter (D) and height $(H)$, shape $(D / H))$, acidity, and gross revenue $(G R)$.

\begin{tabular}{|c|c|c|c|c|c|}
\hline & $\begin{array}{c}D \\
(\mathrm{~mm})\end{array}$ & $\begin{array}{c}\mathbf{H} \\
(\mathrm{mm})\end{array}$ & $\mathrm{D} / \mathrm{H}$ & Acidity (\%) & $\begin{array}{c}\mathrm{GR} \\
\left(€ \mathrm{ha}^{-1}\right)\end{array}$ \\
\hline \multicolumn{6}{|l|}{2017} \\
\hline $\mathrm{T} 1$ & $74.7 \mathrm{e}$ & $71.9 \mathrm{~b}$ & $1.037 \mathrm{~d}$ & $0.080 \mathrm{c}$ & 8914 e \\
\hline $\mathrm{T} 2$ & $74.7 \mathrm{e}$ & $72.4 \mathrm{~b}$ & $1.033 \mathrm{~d}$ & $0.070 \mathrm{~cd}$ & 8998 e \\
\hline $\mathrm{T} 3$ & $74.6 \mathrm{e}$ & $71.7 \mathrm{~b}$ & $1.043 \mathrm{~cd}$ & $0.077 \mathrm{~cd}$ & 8817 e \\
\hline $\mathrm{T} 4$ & $74.2 \mathrm{e}$ & $69.2 \mathrm{~cd}$ & $1.073 \mathrm{~cd}$ & $0.080 \mathrm{~cd}$ & 8718 e \\
\hline $\mathrm{T} 5$ & $74.2 \mathrm{e}$ & $71.6 \mathrm{~b}$ & $1.037 \mathrm{~d}$ & $0.090 \mathrm{bc}$ & 8669 e \\
\hline T6 & $74.6 \mathrm{e}$ & $69.0 \mathrm{~cd}$ & $1.083 \mathrm{c}$ & $0.080 \mathrm{~cd}$ & $8256 \mathrm{e}$ \\
\hline $\mathrm{T} 7$ & $74.1 \mathrm{e}$ & $71.7 \mathrm{~b}$ & $1.033 \mathrm{~d}$ & $0.076 \mathrm{~cd}$ & 8659 e \\
\hline \multicolumn{6}{|l|}{2018} \\
\hline $\mathrm{T} 1$ & $93.1 \mathrm{a}$ & $74.2 \mathrm{ab}$ & $1.253 \mathrm{a}$ & $0.113 \mathrm{a}$ & $16882 \mathrm{a}$ \\
\hline $\mathrm{T} 2$ & $87.6 \mathrm{bc}$ & $71.4 \mathrm{bc}$ & $1.227 \mathrm{ab}$ & $0.077 \mathrm{~cd}$ & $15443 \mathrm{~b}$ \\
\hline T3 & 89.8 b & $73.0 \mathrm{~b}$ & $1.230 \mathrm{ab}$ & $0.093 \mathrm{~b}$ & $16323 \mathrm{ab}$ \\
\hline $\mathrm{T} 4$ & $90.6 \mathrm{~b}$ & $76.0 \mathrm{a}$ & $1.193 \mathrm{~b}$ & $0.087 \mathrm{bc}$ & $16084 \mathrm{ab}$ \\
\hline $\mathrm{T} 5$ & $83.8 \mathrm{~d}$ & $67.1 \mathrm{~cd}$ & $1.253 \mathrm{a}$ & $0.097 \mathrm{~b}$ & $12732 \mathrm{~cd}$ \\
\hline T6 & $86.8 \mathrm{c}$ & $71.9 \mathrm{~b}$ & $1.207 \mathrm{~b}$ & $0.070 \mathrm{~cd}$ & $13761 \mathrm{~cd}$ \\
\hline $\mathrm{T} 7$ & 89.1 bc & $71.3 \mathrm{bc}$ & $1.250 \mathrm{ab}$ & $0.077 \mathrm{~cd}$ & 14772 bc \\
\hline LSD & 2.5 & 2.5 & 0.044 & 0.013 & 1316 \\
\hline
\end{tabular}

Mean values followed by different lower-case letters in each column indicate significant differences at $p \leq 0.05$ using the LSD test. 


\subsection{Crop Profitability}

The gross revenue and the economic value of water were affected by GS and IS ( $p \leq 0.01$; Table 8 ). The gross revenue was also affected by the GS-IS interaction $(p \leq 0.05)$ and, as observed for many factors, in 2017, there were no differences between the different IS, which were in all cases lower than those obtained in 2018 (Table 7). Applying 50\% of the IWR reduced gross revenue in relation to T1 in 2018, particularly when it was applied at the vegetative growth (T5) and at the bulbing (T6) stages. Regarding the economic value of water, lower values were obtained in 2018 than in 2017, and the highest value was obtained with the severe water restriction applied at the bulbing (T7), while the lowest values corresponded to the severe reduction at vegetative growth (T5).

Table 8. Effects of the growing season and the irrigation strategy on the gross revenue (GR) and water economic value (WEV).

\begin{tabular}{|c|c|c|}
\hline & GR $\left(€ \mathrm{ha}^{-1}\right)$ & WEV $\left(€ \mathrm{~m}^{-3}\right)$ \\
\hline \multicolumn{3}{|l|}{ Growing Season (GS) } \\
\hline 2017 & 8719 b & $5.91 \mathrm{a}$ \\
\hline 2018 & $15,142 \mathrm{a}$ & $5.13 \mathrm{~b}$ \\
\hline LSD & 599 & 0.25 \\
\hline \multicolumn{3}{|l|}{ Irrigation Strategies (IS) } \\
\hline $\mathrm{T} 1$ & $12,898 \mathrm{a}$ & $5.22 \mathrm{bc}$ \\
\hline $\mathrm{T} 2$ & $12,220 \mathrm{ab}$ & $5.37 \mathrm{bc}$ \\
\hline T3 & $12,570 \mathrm{ab}$ & $5.55 \mathrm{bc}$ \\
\hline $\mathrm{T} 4$ & $12,401 \mathrm{ab}$ & $5.68 \mathrm{~b}$ \\
\hline $\mathrm{T} 5$ & $10,701 \mathrm{c}$ & $5.14 \mathrm{c}$ \\
\hline T6 & $11,008 \mathrm{c}$ & $5.43 \mathrm{bc}$ \\
\hline $\mathrm{T} 7$ & $11,716 \mathrm{bc}$ & $6.24 \mathrm{a}$ \\
\hline LSD & 1121 & 0.47 \\
\hline ANOVA (df) & \multicolumn{2}{|c|}{$\%$ sum of squares } \\
\hline GS (1) & $86.8^{* *}$ & $35.5^{* *}$ \\
\hline IS (6) & $4.9^{* *}$ & $26.8^{* *}$ \\
\hline GS*IS (6) & $3.3 *$ & $12.9 \mathrm{~ns}$ \\
\hline Residuals (28) & 5.0 & 24.8 \\
\hline Standard deviation & 948 & 0.4 \\
\hline
\end{tabular}

df: degrees of freedom. Mean values followed by different lower-case letters in each column indicate significant differences at $p \leq 0.05$ using the LSD test. $\left.{ }^{* *}{ }^{*}\right)$, indicate significant differences at $p \leq 0.01(p \leq 0.05)$. ns, indicates no significant differences.

\section{Discussion}

The effective precipitation measured during 2017 was 2.6 times higher than that in 2018, and the $\mathrm{ET}_{\mathrm{o}}$ during 2017 was 1.7 times lower than that recorded in 2018, as shown in Figure 1. Overall, it can be stated that for the different parameters that were analysed, when the interaction result was significant, it was because the important rainfall registered in 2017 led to no differences between the IS values, contrary to that obtained in 2018 , whose differences coincided with the average values, unless otherwise indicated. The IWA during 2017 (167 mm for T1) was approximately 50\% lower than that applied during 2018 (331 mm for T1). These volumes are similar to those applied to onions by Martín de Santa Olalla et al. [52] and Zheng et al. [28]. Doorenbos and Kassam [48] and Pérez-Ortolá and Knox [29] reported that the irrigation water requirements of onions ranged between 350 and $550 \mathrm{~mm}$ in the United Kingdom, which was the lowest threshold of the same order as the water requirements in 2018.

The VSWC varied between the GS, with higher values in 2017 (on average, 92.0\% FC) than in 2018 (on average, $86.4 \% \mathrm{FC}$ ), which might be related to the higher precipitation levels and to the lower $\mathrm{ET}_{\mathrm{C}}$ during 2017. The stomatal closure responds earlier to soil water content than to leaf turgor [14] and is different depending on the plant species [53]. The initial plant response to the reduction of water in 
the soil is stomatal closure, directly affecting the plant water status (RWC and MSI) and reducing the assimilation of $\mathrm{CO}_{2}$, as will be discussed later $[14,54]$.

At the beginning of plant growth (establishment stage), both the RWC and MSI were unaffected by the IS, given that all the plants were equally irrigated with water volumes applied that were greater than IWR to ensure adequate plant establishment. These similar values show that all the plants presented a similar water status when the differential irrigation period started. At the end of the vegetative growth stage, both indexes were affected by the GS, IS, and their interaction, which was a consequence of the different rainfall amounts and the corresponding VSWC during the two seasons. In general, it can be stated that the lower values for the RWC and MSI in each stage corresponded to the water restriction applied in the respective stage, with lower values observed for the most severe restriction. It is noteworthy that, in general, when the MSI value has been reduced in one stage, it is not recovered in the rest of the crop cycle. The RWC and MSI values obtained are in accordance with those reported by Semida et al. [24]. On the basis of that study, the RWC and MSI obtained for the deficit irrigation strategies in the present experiments could be related to the lower soil moisture and climate conditions. The leaf water status (and the subsequent plant response) depends on the water deficit in terms of its intensity, duration, and the growth stage when it is applied [16]. In accordance with González and González-Vilar [55], an initial reduction in the leaf RWC (100\%-90\%) induces stomatal closure, reducing cellular growth; lower values of RWC (90\%-80\%) induce changes in the tissue composition and changes in the relative rates of photosynthesis and respiration; while a greater decrease in RWC (below $80 \%$ ) causes changes in metabolism, leading to the cessation of photosynthesis, to an increase of respiration, and to the accumulation of abscisic acid. On the basis of these considerations, the obtained values of the RWC ranging between $74.9 \%$ and $83.9 \%$ could be induced by changes in the relative rates of photosynthesis and respiration, until photosynthesis ceased, and could be related to abscisic acid accumulation, leading to negative effects on biomass production. Water restriction had a negative effect on onion plant biomass (fresh and dry weight of the leaves and bulbs) that was, in general, more pronounced when it was applied during vegetative growth than when applied at the bulb ripening stage. A similar trend was observed for plant height and number of leaves per plant, although the differences were not significant. Zheng et al. [28] reported that water restriction during the onion vegetative growth stage had an irreversible effect from which the plant cannot recover, and led to lower plant height and to lower leaf and bulb biomass. These authors also observed a reduction in bulb dry weight under water restriction at the vegetative growth and bulbing stages.

The HI was not affected by the IS, which agrees with the results reported for many other crops, as yield is often directly related to plant biomass [56]. Under moderate water stress, water deficits lead to reduced biomass production owing to the reduction in canopy size and, in that case, dry matter partitioning is usually not affected, and the HI is maintained in many crops [10], as occurred in this study. These results imply that the RDI did not alter the partitioning of assimilates between onion plant parts.

The SPAD was not affected by the different IS, indicating that deficit irrigation did not affect the chlorophyll content in the leaves. The SPAD average values obtained during this study are slightly higher than those reported by Leskovar et al. [30]. As the bulbing ratio is a common indicator of starting bulb formation $[27,38]$, and considering that there were no differences between IS for the values presented, it can be concluded that plants for all the IS began to form bulbs normally on the same dates, as the plants that were grown with full irrigation.

The yields obtained in the present study under full irrigation in 2018 were similar to those obtained using drip irrigation by Martín de Santa Olalla et al. [33] (until $7.39 \mathrm{~kg} \mathrm{~m}^{-2}$ ) and Leskovar et al. [30] (until $7.90 \mathrm{~kg} \mathrm{~m}^{-2}$ ). The important impact of the GS on yield was probably because of two factors: the different climatic conditions registered in each GS (in 2018, there were higher temperatures and higher radiation (2169 and $2317 \mathrm{MJ} \mathrm{m}^{-2}$ in 2017 and 2018, respectively) and lower rainfall), and to the mildew incidence that took place in 2017 as a consequence of the great rainfall. The mildew incidence, as reported in specialized literature [27,57], leads to an important reduction in yield. 
The results of this study indicated that the bulb yield (yield and MY) decreased more when severe water shortage was applied at the vegetative growth (T5) and bulbing (T6) stages than when it was applied at the bulb ripening stage (T7). Similar results were reported by Bekele and Tilahun [58] and Zheng et al. [28], who observed limited effects of deficit irrigation on onion yield when applied at bulb maturity when compared with the effects when the deficits were applied at the crop development and bulb formation stages. Yield reductions were a consequence of both the lower ABW and the higher percentage of small bulbs (although not significant) that were obtained with T5 and T6. This observation agrees with the results reported for field experiments by Martín de Santa Olalla et al. [33] and Zheng et al. [28], in that the water shortages applied during the growth and bulbification stages led to higher percentages of small bulbs. Full irrigation led to the highest average bulb weight, decreasing the ABW with the water reduction, in accordance with the results obtained by Kumar et al. [59] and Dirirsa et al. [60].

In addition to genetic characteristics, for example, the cultivar used, the most important factors for the induction of onion bolting are low temperatures (generally from 5 to $12{ }^{\circ} \mathrm{C}$ ) at certain physiological conditions of the plant (the number of leaves is generally considered as the best indicator [27]). It is thus logical that bolting was influenced only by the GS and not by the IS, as the plants of all the IS presented the same physiological conditions (at harvesting, there were no significant differences either in height or in the number of leaves of the plants subjected to the different IS).

In addition to genotypes, soil types, and agronomic practices, climatic conditions play an important role in IWUE values. The IWUE results are consistent with those reported by Kumar et al. [59] and Patel and Rajput [61], in the sense that the higher IWUE values were obtained with the lower IWA. Tolk and Howell [20] indicated that maximum IWUE usually occurs at an evapotranspiration level that is generally less than the maximum evapotranspiration, thereby suggesting that irrigating to achieve a maximum yield would not correspond to the most efficient use of irrigation water, as occurred in this study. Bekele and Tilahun [58], in a study carried out in Ethiopia without rainfall during the experimental period, stated that all deficit irrigation strategies increased the water use efficiency of onions, from $6 \%$ when water stress was applied during vegetative growth to $13 \%$ when the IWA was reduced to $75 \%$ of the optimum application throughout the growing season. Martín de Santa Olalla et al. [33] obtained the highest IWUE using the following strategy: 80\% ET during vegetative growth, $90 \%$ ET during bulbing, and 50\% ET during bulb ripening.

For the different water restriction stages, the MY increased linearly with the IWA, with high correlation coefficients $(r \geq 0.95)$; therefore, reducing the water applied at any stage would decrease the MY relative to full irrigation. Similar positive linear relationships were reported by Zheng et al. [28], indicating that the IWA did not exceed the maximum crop water demands. Kumar et al. [59] presented second-order relationships between yield and IWA, with negative quadratic effects, indicating that the increase in onion yield was not proportional to the increment in IWA because the higher values of IWA exceeded the maximum crop water demands. The negative linear relationships between IWUE and IWA presented lower correlation coefficients $(r \geq-0.55)$ owing to the important differences of IWR between years, as a consequence of rainfall.

In this study, the $\mathrm{K}_{\mathrm{y}}$ values were $1.66,1.75$, and 0.75 for the vegetative growth, bulbing, and bulb ripening stages, respectively, and these values are consistent with those obtained by Dirirsa et al. [60]. If $\mathrm{K}_{\mathrm{y}}$ is lower than 1 , a crop can be considered to be tolerant to water deficits, while if it is greater than 1 , this value indicates that the crop response is sensitive to water deficits $[22,48]$. The lower $\mathrm{K}_{\mathrm{y}}$ seen in the bulb ripening stage indicates that this is a less sensitive period for applying water restriction, suggesting that, in the case of deficit irrigation application, the restriction should be applied during the bulb ripening stage.

The RDI led to an important reduction in bulb size (diameter and height), particularly when the severe water stress was applied during the vegetative growth (T5), in agreement with the ABW. Similar reductions in the average bulb weight and size with water restrictions were observed by Leskovar et al. [30], Zheng et al. [28], and Patel and Rajput [61] in India. 
The IS did not significantly affect bulb firmness or the SSC, in agreement with reports in the literature [43,62]. The absence of differences between the IS for the bulb SSC could be related to the fact that all bulbs had a similar dry matter content and, therefore, a similar soluble solids dilution.

Bulb acidity values were slightly lower than those reported by Rodríguez et al. [63], with higher values obtained in bulbs subjected to full irrigation. As the SSC was not affected by the IS, and because, for the determination of the MI, the acidity appears in the denominator, the trend of MI values is practically the inverse of acidity. Reducing the IWA to $50 \%$ of the IWR at the bulbing stage (T6) at the bulb ripening stage (T7) accelerated bulb maturation.

Considering the current climatic conditions in irrigated areas, particularly in dry regions, it is of great importance to increase IWUE and, in turn, the water economic value. Applying moderate (T4) or severe (T7) deficit irrigation at the bulb ripening stage led to a low reduction in gross revenue relative to full irrigation ( $4 \%$ and $9 \%$, respectively), but these irrigation strategies led to an increase in the water economic value ( $9 \%$ and $20 \%$, respectively) relative to full irrigation. The moderate water shortage at the vegetative growth (T2) and bulbing (T3) stages presumed a low reduction in gross revenue (below $5 \%$ ), but the water savings that they provided were small (below $8 \%$ ). The greatest reductions in gross revenue were obtained with severe water stress at the vegetative growth (T5) and bulbing stages (T6) (17\% and $15 \%$, respectively), which seriously questioned the economic viability of the crop. The average water economic values obtained in this research ranged from $5.14 € \mathrm{~m}^{-3}$ (T5) to $6.24 € \mathrm{~m}^{-3}$ (T7), and these values are similar to the ranges of those obtained for other horticultural crops in the area, such as for chufa (Cyperus esculentus, L. var. sativus Boeck.; $4.08 € \mathrm{~m}^{-3}$, [64]) and watermelon $\left(6.14 € \mathrm{~m}^{-3},[25]\right)$, both in field conditions.

Overall, it can be stated that if water is not a limiting factor, irrigation to full requirements should be applied. Nevertheless, if water is scarce, applying $50 \%$ of the IWR during the bulb ripening stage (T7) may lead to important water savings (approximately $22 \%$ ), while decreasing the MY and, consequently, the gross revenue, by 9\%. An intermediate advised IS involves reducing the IWA during the bulb ripening stage to $75 \%$ of the IWR (T4), which would slightly reduce the MY (4\%), with water savings of approximately $11 \%$.

\section{Conclusions}

Field experiments were carried out in Spain under Mediterranean conditions to study the effects of regulated deficit irrigation on the growth, plant water status, yield response, bulb quality, irrigation water use efficiency, and crop profitability of the onion 'Hamaemi'. Moderate water shortage $(75 \%$ of the IWR) at the vegetative growth and bulbing stages presumed a low reduction in gross revenue, but with small water savings. Severe deficit irrigation (50\% of the IWR) applied at the vegetative growth and bulbing stages negatively affected the biomass production, water status, and marketable yield. Reducing the water applied to $50 \%$ of the water requirements during the bulb ripening stage led to important water savings and improved IWUE when compared with full irrigation while reducing, although not drastically, the marketable yield and, therefore, the gross revenue; thus, this strategy can be recommended in cases of severe water shortage conditions. Reducing the irrigation water applied to $75 \%$ of the water requirement during the bulb ripening stage resulted in a slight reduction in yield, but with similar IWUE to that obtained with full irrigation; therefore, it could be considered as a recommended strategy for onion production under mild water shortage.

Author Contributions: In this research article, authors contributions are as follows: A.A.: data curation, formal analysis, investigation, writing-original draft; B.P.: project administration, conceptualization, supervision, writing-review and editing, visualization, methodology; I.N.: data curation, investigation; C.B.: project administration, conceptualization, supervision, methodology; N.P.S.: formal analysis, writing-review and editing, visualization, supervision, methodology.

Funding: This research received no external funding

Conflicts of Interest: The authors declare no conflict of interest. 


\section{References}

1. Food and Agriculture Organization Faostat. Food and Agriculture Data; Food and Agriculture Organization: Rome, Italy, 2018; Available online: http://www.fao.org/faostat/en/\#data/QC (accessed on 10 June 2019).

2. Galindo, A.; Collado-González, J.; Griñán, I.; Corell, M.; Centeno, A.; Martín-Palomo, M.J.; Girón, I.F.; Rodríguez, P.; Cruz, Z.N.; Memmi, H.; et al. Deficit irrigation and emerging fruit crops as a strategy to save water in Mediterranean semiarid agrosystems. Agric. Water Manag. 2018, 202, 311-324. [CrossRef]

3. Apostolaki, S.; Akinsete, E.; Tsani, S.; Koundouri, P.; Pittis, N.; Levantis, E. Assessing the effectiveness of the WFD as a tool to address different levels ofwater scarcity based on two case studies of the mediterranean region. Water 2019, 11, 840. [CrossRef]

4. Food and Agriculture Organization Aquastat. AQUASTAT-FAO's Global Information System on Water and Agriculture; Food and Agriculture Organization: Rome, Italy, 2018; Available online: http://www.fao.org/nr/ water/aquastat/data/query/index.html?lang=en (accessed on 10 June 2019).

5. Chartzoulakis, K.; Bertaki, M. Sustainable water management in agriculture under climate change. Agric. Agric. Sci. Procedia 2015, 4, 88-98. [CrossRef]

6. WWAP (World Water Assessment Programme); UNESCO. The United Nations World Water Development Report 2015: Water for a Sustainable World; UNESCO: Paris, France, 2015.

7. Pereira, L.S. Trends for irrigated agriculture in the Mediterranean region: Coping with water scarcity. Eur. Water 2004, 7, 47-64.

8. Mancosu, N.; Snyder, R.; Kyriakakis, G.; Spano, D. Water scarcity and future challenges for food production. Water 2015, 7, 975-992. [CrossRef]

9. Bessembinder, J.J.E.; Leffelaar, P.A.; Dhindwal, A.S.; Ponsioen, T.C. Which crop and which drop, and the scope for improvement of water productivity. Agric. Water Manag. 2005, 73, 113-130. [CrossRef]

10. Fereres, E.; Soriano, M.A. Deficit irrigation for reducing agricultural water use. J. Exp. Bot. 2007, 58, 147-159. [CrossRef]

11. Molden, D.; Oweis, T.; Steduto, P.; Bindraban, P.; Hanjra, M.A.; Kijne, J. Improving agricultural water productivity: Between optimism and caution. Agric. Water Manag. 2010, 97, 528-535. [CrossRef]

12. Malek, Ž.; Verburg, P.H. Adaptation of land management in the Mediterranean under scenarios of irrigation water use and availability. Mitig. Adapt. Strateg. Glob. Chang. 2017, 23, 821-837. [CrossRef]

13. Pereira, L.S.; Oweis, T.; Zairi, A. Irrigation management under water scarcity. Agric. Water Manag. 2002, 57, 175-206. [CrossRef]

14. Costa, J.M.; Ortuño, M.F.; Chaves, M.M. Deficit irrigation as a strategy to save water: Physiology and potential application to horticulture. J. Integr. Plant Biol. 2007, 49, 1421-1434. [CrossRef]

15. Capra, A.; Consoli, S.; Scicolone, B. Water management strategies under deficit irrigation. J. Agric. Eng. 2008, 39, 27-34. [CrossRef]

16. Chai, Q.; Gan, Y.; Zhao, C.; Xu, H.L.; Waskom, R.M.; Niu, Y.; Siddique, K.H.M. Regulated deficit irrigation for crop production under drought stress. A review. Agron. Sustain. Dev. 2016, 36, 1-21. [CrossRef]

17. Abrisqueta, I.; Ayars, J.E. Effect of alternative irrigation strategies on yield and quality of Fiesta raisin grapes grown in California. Water 2018, 10, 583. [CrossRef]

18. Nadeem, M.; Li, J.; Yahya, M.; Sher, A.; Ma, C.; Wang, X.; Qiu, L. Research progress and perspective on drought stress in legumes: A review. Int. J. Mol. Sci. 2019, 20, 2541. [CrossRef] [PubMed]

19. Geerts, S.; Raes, D. Deficit irrigation as an on-farm strategy to maximize crop water productivity in dry areas. Agric. Water Manag. 2009, 96, 1275-1284. [CrossRef]

20. Tolk, J.A.; Howell, T.A. Water use efficiencies of grain sorghum grown in three USA southern Great Plains soils. Agric. Water Manag. 2003, 59, 97-111. [CrossRef]

21. Howell, T.A. Challenges in increasing water use efficiency in irrigated agriculture. In Proceedings of the International Symposium on Water and Land Management for Sustainable Irrigated Agriculture, Adana, Turkey, 4-8 April 2006.

22. Steduto, P.; Hsiao, T.C.; Fereres, E.; Raes, D. Crop Yield Response to Water; Irrigation and Drainage Paper No. 66; Food and Agriculture Organization (FAO): Rome, Italy, 2012.

23. Rao, N.K.S. Onion. In Abiotic Stress Physiology of Horticultural Crops; Rao, N.K.S., Shivashankara, K.S., Laxman, R.H., Eds.; Springer: New Delhi, India, 2016; pp. 133-149. [CrossRef] 
24. Semida, W.M.; Abd El-Mageed, T.A.; Mohamed, S.E.; El-Sawah, N.A. Combined effect of deficit irrigation and foliar-applied salicylic acid on physiological responses, yield, and water-use efficiency of onion plants in saline calcareous soil. Arch. Agron. Soil Sci. 2017, 63, 1227-1239. [CrossRef]

25. Abdelkhalik, A.; Pascual-Seva, N.; Nájera, I.; Giner, A.; Baixauli, C.; Pascual, B. Yield response of seedless watermelon to different drip irrigation strategies under Mediterranean conditions. Agric. Water Manag. 2019, 212, 99-110. [CrossRef]

26. Bosch Serra, A.D.; Currah, L. Agronomy of onion. In Allium Crop Science: Recent Advances; Rabinowitch, H.D., Currah, L., Eds.; CABI: Wallingford, UK, 2002; pp. 187-232, ISBN 9780851995106.

27. Brewester, J.L. Onions and Other Vegetable Alliums, 2nd ed.; CABI: Wallingford, UK, 2008; Volume 15, ISBN 9781845934248.

28. Zheng, J.; Huang, G.; Wang, J.; Huang, Q.; Pereira, L.S.; Xu, X.; Liu, H. Effects of water deficits on growth, yield and water productivity of drip-irrigated onion (Allium cepa L.) in an arid region of Northwest China. Irrig. Sci. 2013, 31, 995-1008. [CrossRef]

29. Pérez-Ortolá, M.; Knox, J.W. Water relations and irrigation requirements of onion (Allium cepa L.): A review of yield and quality impacts. Exp. Agric. 2015, 51, 210-231. [CrossRef]

30. Leskovar, D.I.; Agehara, S.; Yoo, K.; Pascual-Seva, N. Crop coefficient-based deficit irrigation and planting density for onion: Growth, yield, and bulb quality. HortScience 2012, 47, 31-37. [CrossRef]

31. Rop, D.K.; Kipkorir, E.C.; Taragon, J.K. Effects of deficit irrigation on yield and quality of onion crop. J. Agric. Sci. 2016, 8, 112-126. [CrossRef]

32. Kadayifci, A.; Tuylu, G.I.; Ucar, Y.; Cakmak, B. Crop water use of onion (Allium cepa L.) in Turkey. Agric. Water Manag. 2005, 72, 59-68. [CrossRef]

33. Martín de Santa Olalla, F.; Domínguez-Padilla, A.; López, R. Production and quality of the onion crop (Allium cepa L.) cultivated under controlled deficit irrigation conditions in a semi-arid climate. Agric. Water Manag. 2004, 68, 77-89. [CrossRef]

34. Soil Survey Staff. Keys to Soil Taxonomy, 12th ed.; USDA-NRCS: Washington, DC, USA, 2014; ISBN 0926487221.

35. Verheye, W. Agro-climate-based land evaluation systems. In Land Use, Land Cover and Soil Sciences: Land Evaluation; Verheye, W., Ed.; UNESCO-EOLSS; Eolss Publishers: Paris, France, 2009; Volume II, pp. 130-159.

36. Fundación Cajamar. Memorias de Actividades, Resultados de Ensayos Hortícolas; Fundación Cajamar Valencia: Valencia, Spain, 2016; Volume 2017, p. 2018.

37. Sonneveld, C.; Straver, N. Nutrient Solutions for Vegetables and Flowers Grown in Water or Substrates. Voedingspolossingen Glastijnbouw 1994, 88, 1-31.

38. Miguel, A. Cebolla. Cultivos Hortícolas al Aire Libre; Maroto, J.V., Baixauli, C., Eds.; Cajamar Caja Rural: Almería, Spain, 2017; pp. 165-202.

39. Allen, R.G.; Pereira, L.S.; Raes, D.; Smith, M. Crop Evapotranspiration: Guidelines for Computing Crop Requirements; Irrigation and Drainage Paper No. 56; Food and Agriculture Organization (FAO): Rome, Italy, 1998.

40. Stamm, G.G. Problems and procedures in determining water supply requirements for irrigation projects. In Irrigation of Agricultural Lands, Agronomy Monograph 11; Hagan, R.M., Haise, H.R., Edminster, T.W., Eds.; American Society of Agronomy: Madison, WI, USA, 1967; pp. 771-785.

41. Pascual-Seva, N.; San Bautista, A.; López-Galarza, S.; Maroto, J.V.; Pascual, B. Response of drip-irrigated chufa (Cyperus esculentus L. var. sativus Boeck.) to different planting configurations: Yield and irrigation water-use efficiency. Agric. Water Manag. 2016, 170, 140-147. [CrossRef]

42. IVIA (Instituto Valenciano de Investigaciones Agrarias). Cálculo de Necesidades de Riego. Available online: http://riegos.ivia.es/calculo-de-necesidades-de-riego (accessed on 15 June 2019).

43. Enciso, J.; Wiedenfeld, B.; Jifon, J.; Nelson, S. Onion yield and quality response to two irrigation scheduling strategies. Sci. Hortic. 2009, 120, 301-305. [CrossRef]

44. Hayat, S.; Ali, B.; Hasan, S.A.; Ahmad, A. Brassinosteroid enhanced the level of antioxidants under cadmium stress in Brassica juncea. Environ. Exp. Bot. 2007, 60, 33-41. [CrossRef]

45. Rady, M.M. Effect of 24-epibrassinolide on growth, yield, antioxidant system and cadmium content of bean (Phaseolus vulgaris L.) plants under salinity and cadmium stress. Sci. Hortic. 2011, 129, 232-237. [CrossRef]

46. Turner, N.C. Agronomic options for improving rainfall-use efficiency of crops in dryland farming systems. J. Exp. Bot. 2004, 55, 2413-2425. [CrossRef] [PubMed] 
47. Cabello, M.J.; Castellanos, M.T.; Romojaro, F.; Martínez-Madrid, C.; Ribas, F. Yield and quality of melon grown under different irrigation and nitrogen rates. Agric. Water Manag. 2009, 96, 866-874. [CrossRef]

48. Doorenbos, J.; Kassam, A.H. Yield Response to Water; Irrigation and Drainage Paper No. 33; Food and Agriculture Organization (FAO): Rome, Italy, 1979.

49. Pascual-Seva, N.; San Bautista, A.; López-Galarza, S.; Maroto, J.V.; Pascual, B. Response of nutsedge (Cyperus esculentus L. var sativus Boeck.) tuber production to drip irrigation based on volumetric soil water content. Irrig. Sci. 2015, 33, 31-42. [CrossRef]

50. MAPA (Ministerio de Agricultura, Pesca y Alimentación). Anuario de Estadística Agraria; MAPA: Madrid, Spain, 2016. Available online: https://www.mapa.gob.es (accessed on 25 June 2019).

51. Statistical Graphics Corporation. Statgraphics Centurion XVI; Statistical Graphics Corporation: Rockville, MD, USA, 2014.

52. Martín de Santa Olalla, F.; de Juan Valero, J.A.; Cortés, C.F. Growth and production of onion crop (Allium cepa L.) under different irrigation schedulings. Eur. J. Agron. 1994, 3, 85-92. [CrossRef]

53. Fahad, S.; Bajwa, A.A.; Nazir, U.; Anjum, S.A.; Farooq, A.; Zohaib, A.; Sadia, S.; Nasim, W.; Adkins, S.; Saud, S.; et al. Crop production under drought and heat stress: Plant responses and management options. Front. Plant Sci. 2017, 8, 1147. [CrossRef] [PubMed]

54. Du, T.; Kang, S.; Zhang, J.; Davies, W.J. Deficit irrigation and sustainable water-resource strategies in agriculture for China's food security. J. Exp. Bot. 2015, 66, 2253-2269. [CrossRef] [PubMed]

55. González, L.; González-Vilar, M. Determination of relative water content. In Handbook of Plant Ecophysiology Techniques; Reigosa Roger, M.J., Ed.; Springer: Dordrecht, The Netherlands, 2001; pp. 207-212, ISBN 978-0-306-48057-7.

56. Clemmens, A.J.; Molden, D.J. Water uses and productivity of irrigation systems. Irrig. Sci. 2007, 25, $247-261$. [CrossRef]

57. Cebolla, V.; Giner, A.; Aguilar, J.M.; Baixauli, C.; Núñez, A.; Nájera, I. Estrategias para control del mildiu en cebolla. In Jornadas de Actualización en Horticultura; Instituto Valenciano de Investigaciones Agrarias, Moncada: Valencia, Spain, 2012.

58. Bekele, S.; Tilahun, K. Regulated deficit irrigation scheduling of onion in a semiarid region of Ethiopia. Agric. Water Manag. 2007, 89, 148-152. [CrossRef]

59. Kumar, S.; Imtiyaz, M.; Kumar, A.; Singh, R. Response of onion (Allium cepa L.) to different levels of irrigation water. Agric. Water Manag. 2007, 89, 161-166. [CrossRef]

60. Dirirsa, G.; Woldemichael, A.; Hordofa, T. Effect of deficit irrigation at different growth stages on onion (Allium cepa L.) production and water productivity at Melkassa, Central Rift Valley of Ethiopia. Acad. Res. J. Agric. Sci. Res. 2017, 5, 358-365. [CrossRef]

61. Patel, N.; Rajput, T.B.S. Effect of deficit irrigation on crop growth, yield and quality of onion in subsurface drip irrigation. Int. J. Plant Prod. 2013, 7, 417-436.

62. Leskovar, D.I.L.; Chenping, X.U.; Gehara, S.A.; Harma, S.P.S.; Rosby, K.C. Irrigation Strategies for Vegetable Crops in Water-Limited Environments. J. Arid Land Stud. 2014, 24, 133-136.

63. Rodriguez, B.; Rodriguez, C.T.; Rodriguez, E.R.; Romero, C.D. Organic Acid Contents in Onion Cutivars (Allium cepa L.). J. Agric. Food Chem. 2008, 56, 6512-6519. [CrossRef] [PubMed]

64. Pascual-Seva, N.; San Bautista, A.; López-Galarza, S.; Maroto, J.V.; Pascual, B. Influence of different drip irrigation strategies on irrigation water use efficiency on chufa (Cyperus esculentus L. var. sativus Boeck.) crop. Agric. Water Manag. 2018, 208, 406-413. [CrossRef]

(C) 2019 by the authors. Licensee MDPI, Basel, Switzerland. This article is an open access article distributed under the terms and conditions of the Creative Commons Attribution (CC BY) license (http://creativecommons.org/licenses/by/4.0/). 